\title{
THE EFFECT OF TURBOCHARGING ON PERFORMANCE AND EMISSION CHARACTERISTICS FOR LHR ENGINE USING ALCOHOLIC BLENDS OF BIODIESEL: REVIEW
}

\author{
Ch.Sravanthi ${ }^{1}$, A .Aruna Kumari ${ }^{2}$, K.Vijaya Kumar Reddy ${ }^{3}$ \\ ${ }^{1}$ Student, M.Tech, Mechanical Engineering Department, JNTUCEH, Hyderabad \\ ${ }^{2}$ Professor, Mechanical Engineering Department, JNTUCEH, Hyderabad \\ ${ }^{3}$ Professor, Mechanical Engineering Department, JNTUCEH, Hyderabad
}

\begin{abstract}
With the depletion of fossil fuel resources and increase in pollution level leads to researches to concentrate much for the development of renewable fuels for the existing diesel engines. Currently more than $95 \%$ of the biodiesel is produced from edible oils. Producing biodiesel using edible oil may leads to shortage towards eatables and also increases in the cost. Nonedible oil is the alternative to solve this problem. But any alternative fuel which finds suitable as substitute to diesel is comparatively inferior to diesel in performance, emission and combustion characteristics. To bridge this gap various technologies are developed. However in this work an attempt will be made to enhance and optimize fuel properties like pour point, flash point, cloud point, viscosity etc. This can be carried by two means. They are LHR engine concept and turbocharger. In diesel engines maximum amount of heat is lost to cooling medium. For better performance of the engine, improved combustion, reduced emissions, temperature and pressure of in cylinder are responsible which are controlled by cooling rate. Under these circumstances, material selection of components is the main criteria. One of the most promising ceramic materials known for its low density, high thermal stability in severe chemical environments is mullite. Further low thermal conductivity, strength and creep behaviour of this material are also suitable.100 microns and 500 microns thickness mullite thermal barrier coating on the piston head is to be considered for experimental purpose. The density of air entering the cylinder decreases in the insulated engine. Thus the volumetric efficiency of the LHR engine decreases. Turbocharger will be used in order to increase the volumetric efficiency and engine output.
\end{abstract}

Keywords -Turbocharging, LHR Engine, Biofuel, 4 Stroke Single Cylinder Kirloskar Diesel Engine. $* * *$

\section{INTRODUCTION}

For a country to develop economically agriculture, transportation, industrialization, electricity sectors are important. The transportation sector plays a crucial role among them because in day to day life commodities should reach the destination on time with optimum travelling cost. Crude oil is the major source of energy in transportation sector. In 2014 .India had the fourth place in the world in consuming oil and petroleum products. $78.6 \%$ of India's oil consumption included oil imports during 2014-15. According to OPEC's (Organization of the Petroleum Exploring Countries) monthly oil market report India's oil demand reached 4.1MMbpd (Million Barrels per Day) in 2015. It is increased $7 \%$ more compared to 2014.In February 2016 it has reached to 4.6MMbpd resulting in $0.48 \mathrm{MMbpd}$ increment in demand compared to January 2016. That was $12 \%$ more in oil consumption with the previous year. This indicates that fuel consumption has been increasing drastically. With the increase in energy demand, depletion of fossil fuels and environmental pollution it is high time to switch over to alternative fuels.

\section{ALTERNATIVE FUELS}

Alternative fuels for IC engines are as follows

- Methanol and ethanol (alcoholic fuels)
- Natural gas (compresses or liquefied)

- Liquefied petroleum gas

- Hydrogen

- Electricity(Batteries and Fuel cells)

- Biodiesel

\section{Methanol and Ethanol (Alcoholic Fuels)}

Merits

- Energy sources for their manufacture (especially for ethanol) are renewable in nature.

- $\quad \mathrm{PM}$ emissions are lower than gasoline engines due to clean burning characteristics.

- Air toxic emissions such as benzene and 1,3 butadiene are lower

- Aldehyde emissions such as formaldehyde and acetaldehyde are higher resulting in less photochemical activity and ozone forming potential

\section{Demerits}

- Unburned fuel emissions are higher during cold starting/warm up phases.

- Alcohols especially ethanol corrosive in nature.

- Alcohols are not easily miscible with diesel fuels. 


\section{Natural Gas (compressed/liquefied)}

\section{Merits}

- It has high antiknock quality.

- It has high compression ratio around 11:1 resulting in improvement in fuel efficiency and reduction in $\mathrm{CO} 2$ emissions.

- It has less $\mathrm{CO}$ emissions and very low PM emissions.

- Unburned fuel emissions are lower during cold starting/warm up phases.

\section{Demerits}

- Natural gas is stored in high pressure cylinders as CNG which takes a lot of space.

- Resources to establish number of gas stations are not abundant in India.

\section{Liquefied Petroleum Gas}

\section{Merits}

- Gaseous state of LPG gives it a good cold starting/warm up characteristics results in lower $\mathrm{HC}$ emissions.

- PM emissions are negligible.

- It has higher octane number.

\section{Demerits}

- Variation in propane/butane ratio.

- Needs technological development in bi-fuel vehicles.

\section{Hydrogen}

\section{Merits}

- It has a potential to reduce greenhouse gases and $\mathrm{CO}_{2}$ emissions.

- It emits no $\mathrm{HC}, \mathrm{CO}, \mathrm{CO}_{2}$ emissions but a smaller amount will be traced due to combustion of lubricating oil.

- There can be a danger of backfire and induction ignition.

\section{Demerits}

- It produces toxic $\mathrm{NO}_{\mathrm{X}}$ emissions.

- Storage of hydrogen need high capital cost.

\section{Electricity (Batteries and Fuel Cells)}

\section{Merits}

- Battery powered electric vehicles have zero emissions.

- Hydrogen fuel cells have water vapor and heat in their emissions

- Capable of producing instant torque and smoother acceleration.

\section{Demerits}

- Production cost is high.

- Batteries are not suitable for the places where power shortage is there.

- Recharge time is longer for batteries.

\section{Biodiesel}

\section{Merits}

- The amount of sulfur present is very less.

- Due to presence of oxygen, $\mathrm{CO}$ emissions are reduced.

- Lower PM emissions results due to advancement of dynamic injection timing.

- It is biodegradable and nontoxic in nature.

\section{Demerits}

- $\mathrm{NO}_{\mathrm{x}}$ emissions increases slightly due to advancement of dynamic injection timing.

- It has lower calorific value.

- Heating value is low.

\section{SELECTION OF ALTERNATIVE FUEL}

Due to its biodegradability, renewability, nontoxicity and [1] ecofriendly nature biodiesel is selected as the best alternative fuel for IC engines. Biodiesel can be produced from vegetable oils (edible and nonedible), animal fats, used cooking oils, algae and animal fats. Nowadays Usage of edible oils and animal fats create food shortage for the population in developing country like India. Nonedible oils serve the option of producing biodiesel in an economical way.

Biodiesel can be produced from different processes such as

- Direct use and blending

- Micro emulsion process

- Thermal cracking

- Transesterification

Among these processes transesterification is economical in a way that the production of biodiesel is easy and quality of the biodiesel is good.

\section{TRANESTERIFICATION}

Vegetable oils have high viscosity because of long chain fatty acids. Transesteification [2] is a chemical reaction in which long chain fatty acids are converted to monoalkyl esters with the reaction with lower alcohols (especially methanol). In this reaction catalyst is used like sodium hydroxide $(\mathrm{NAOH})$,potassium hydroxide $(\mathrm{KOH})$.biodiesel is fatty acid methyl ester.

As vegetable oil cannot be used directly because of its high viscosity, it has to be converted to biodiesel to meet the requirements of IC engine's combustion compatability. Thus transesterification process helps in reducing viscosity of vegetable oil. Transesterification is an equilibrium process in which excess alcohol is needed for the reaction to be completed. 


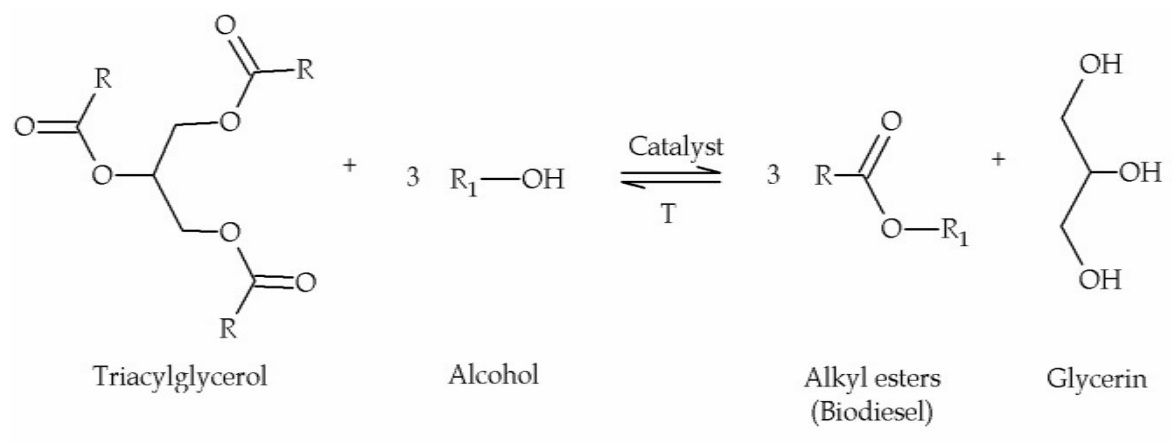

$\mathrm{R}_{r} \mathrm{R}_{1}$ : alkyl chain with different lenghts and/or saturation degrees

Fig.1.Production of Biodiesel from Transesterification

\section{PROBLEMS ASSOCIATED WITH}

\section{BIODIESEL IN USING AS AN ALTERNATIVE}

\section{FUEL}

There are two main problems with biodiesel in using as an alternative fuel. They are poor cold flow properties [3] and stability. Cold flow properties are cloud point, pour point and cold filter pugging point. Poor stability is because of oxidation of biodiesel, increased rate of oxidation at higher temperatures and inability of fuel to resist its physical and chemical properties in storage.

\section{METHODS TO IMPROVE COLD FLOW PROPERTIES OF BIODIESEL}

To improve cold flow properties of biodiesel methods are developed as shown in fig. 2 .

- Using materials which has unsaturated fatty acids in greater percentage.

- To decrease the freezing point blending can be done with petroleum fuel.

- Reduction of saturated fatty acids is obtained with winterization.

- Improvement in crystal morphology obtained by using additives.

- Biodiesel structures are modified with the utilization of branched alcohols.

- Hydroisomerization, ozonisation and epoxidation are the techniques in which treatment is done with reactions.

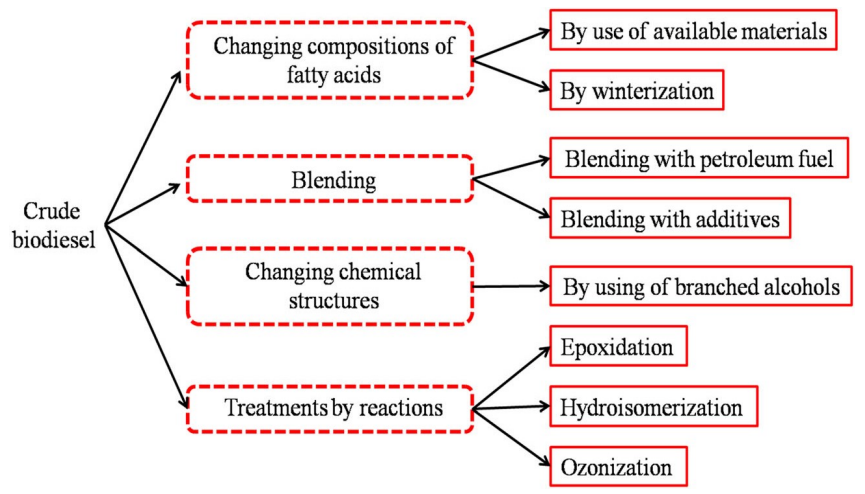

Fig.2. potential methods to improve cold flow properties of biodiesel
Best method of improving cold flow properties of biodiesel is blending with petroleum [5] fuel. Ethanol is the option for so many years. The reason is mixing with diesel causes increased rates of ignition delays, increased thermal efficiency, increased rated premixed combustion and reduced exhaust smoke. But alcohol is immiscible with diesel. Addition of biodiesel to alcoholic diesel blends improves solubility of the alcohol and the mixture will be stable for longer periods.

\section{ENERGY CRITERIA IN IC ENGINE}

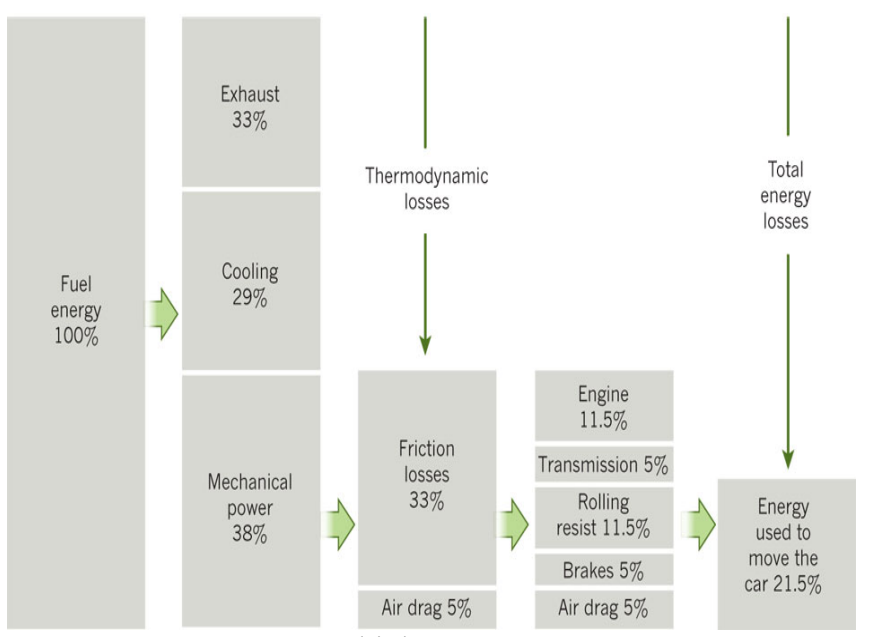

Fig .3.Vehicle Energy Losses

The fuel energy is $100 \%$. But $100 \%$ of it is not utilized for the engine to run. There are thermodynamic losses, friction losses and air drag which contribute a total loss of $78.5 \%$ of total fuel energy. The main advancements in IC engines are as follows

- Engine design

- Material selection

- Timing controls

- Fuels and combustion

Concerning fuels and combustion thermodynamic losses can be minimized by two techniques namely LHR engine and turbocharger. 


\section{THERMAL BARRIER COATING}

Thermal barrier coating is an insulating material in the combustion [6] chamber. Advantages of thermal barrier coating is as follows

- It can sustain the combustion gas temperature

- Decreases viscosity of fuel

- Improves thermal efficiency

- Reduces fuel consumption, heat loss.

- Decreases particulate emissions and condensable hydrocarbons.

- Increases the exhaust gas temperature

- Longer life and higher reliability of engine components.

Ceramic materials can be used as thermal barrier coating are given below

- Zirconates

- Yittria Stabilized Zirconia

- Alumina

- Spinel

- Forsterite

- Mullite

\section{Zirconates}

\section{Advantages}

- Thermal conductivity is low.

- Thermal expansion is high.

- Low sintering activity

- Thermal cyclic resistance is good.

\section{Disadvantages}

- Residual stress and coating delamination due to residual stress.

\section{Yittria Stabilized Zirconia}

\section{Advantages}

- Thermal shock resistance

- Thermal conductivity is low.

- High thermal coefficient with 7-8\% yittria stabilized zirconia

\section{Disadvantages}

- Oxygen and corrosion transparent.

- $\quad$ Sintering is possible above $1473 \mathrm{~K}$.

\section{Alumina}

\section{Advantages}

- High hardness in addition with to yittria stabilized zirconia

- High chemical inertness

\section{Disadvantages}

- Thermal conductivity is high.
- Compared with yittria stabilized zirconia it has low thermal expansion.

- Phase transformation at $1273 \mathrm{~K}$.

\section{Spinel}

\section{Advantages}

- It has good chemical properties and also high temperature properties.

\section{Disadvantages}

- It has poor thermal expansion coefficient. So it's II-176 is not reliable as thermal barrier coating.

\section{Forsterite}

Forsterite has high thermal expansion coefficient. So it has good compatibility with the metal.it also has high thermal shock resistance within hundred microns thickness.

\section{Mullite}

\section{Advantages}

- It has low density

- Oxygen resistant compared with yittria stabilized zirconia.

- Stability in severe chemical environments

- Favorable strength and creep behavior

- In high thermal gradients and under thermal shock its low thermal conductivity is advantageous

\section{Disadvantages}

- Large mismatch in thermal expansion coefficient with metallic substrate leads to poor adhesion.

- Mullite crystallizes at 1023-1273K.

Of all the possible thermal barrier materials mullite is the most promising material.it is compound of $\mathrm{SiO}_{2}$ and $\mathrm{Al}_{2} \mathrm{O}_{3}$ with the composition $3 \mathrm{Al}_{2} \mathrm{O}_{3} \cdot \mathrm{SiO}_{2}$. If the temperature variations are high across the coating and surface temperatures are lower compared to gas turbines mullite is the best alternative as the thermal barrier coating material [6].

The exergy available in the exhaust gas increases with the application of thermal barrier coating on the cylinder piston. Ceramic material is an insulating material. So the temperatures in the combustion [7] chamber increases reducing the density of air thus decreasing the volumetric efficiency of the engine. That is why engine requires a boost like turbocharger which serves the purpose of utilizing the exergy of exhaust gas and increasing the volumetric efficiency. 


\section{TURBOCHARGING}

How a turbocharger works

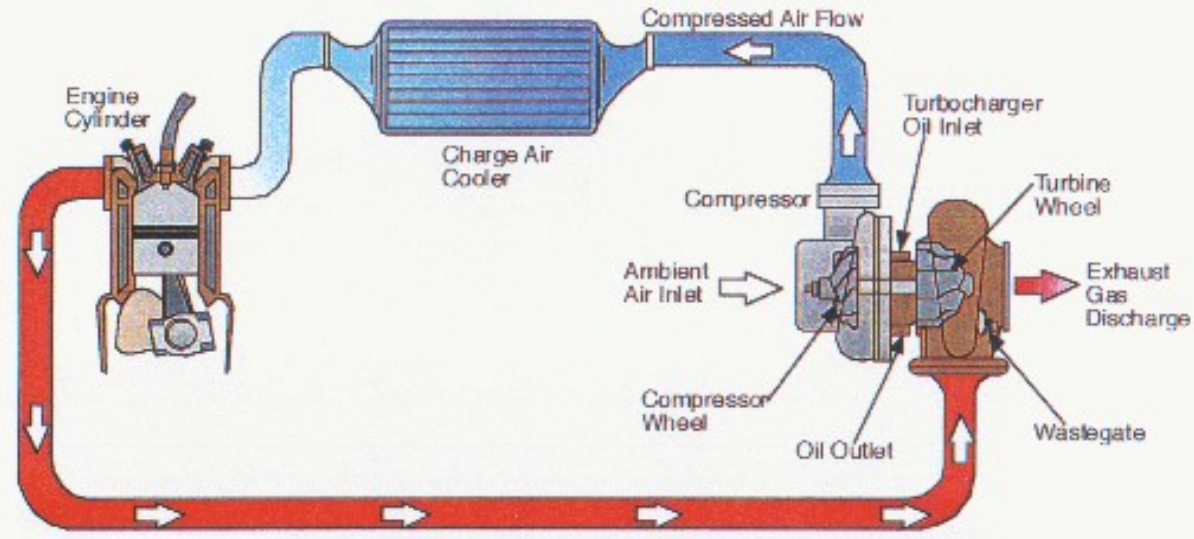

Fig.4. Diagram showing how a turbocharger works

To increase the power output of an IC engine with in same engine size turbocharging is the best to be adopted. Turbocharger compresses the intake air to which fuel is added proportionally so as to increase power output.

Techniques have been developed to increase the volumetric efficiency of a turbocharger to some extent. They are intercooling and twin charging. Intercooling deals with the concept of increasing mass flow rate of charging air by cooling it before going in to combustion chamber. Twin charging is the combination of supercharging and turbocharging. It is possible only when the exhaust gas energy is sufficient to run the turbocharger.

\section{PEER REVIWED RESULTS}

\section{Paper 9}

This study gives the performance, emission combustion and evaluation of CI engine with biofuel.

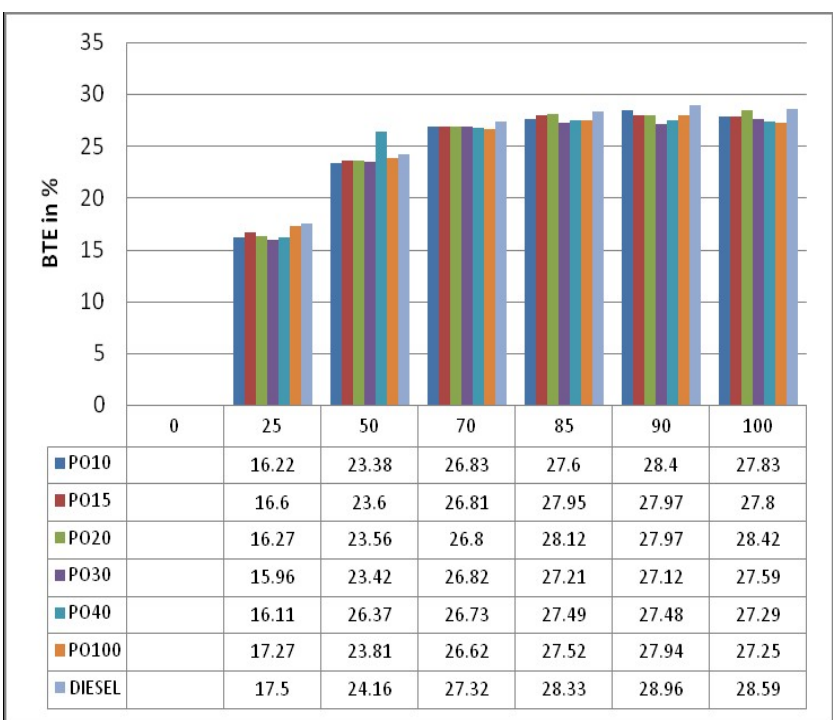

Fig.5. BTE vs. LOAD for All Blends of Palm Oil and Diesel

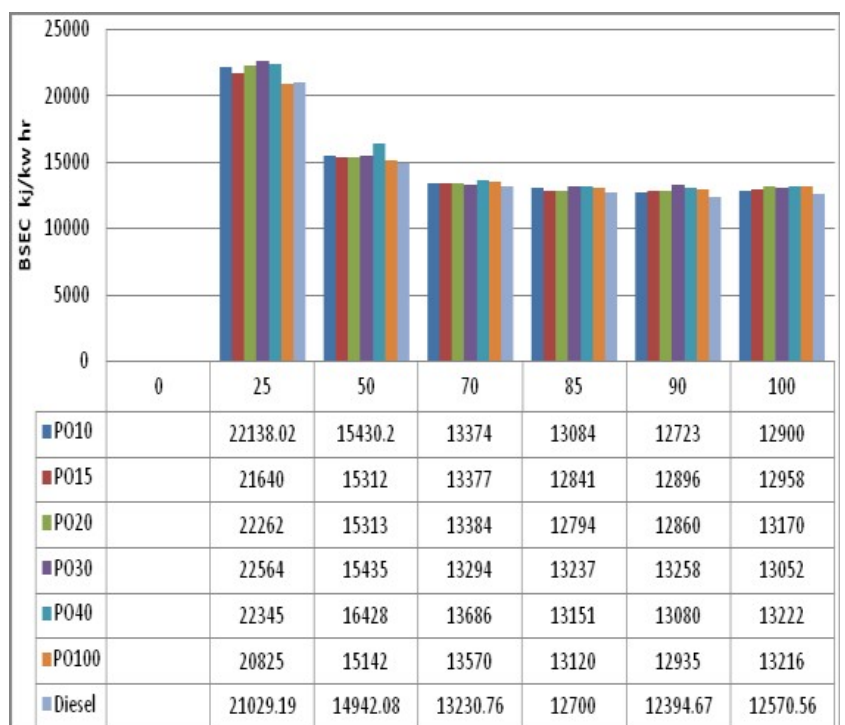

Fig.6. BSEC vs. LOAD for All the blends of Palm Oil and Diesel

\begin{tabular}{|c|c|c|c|c|c|c|c|}
\hline \multirow{7}{*}{$\begin{array}{l}a \\
\Xi \\
\vdots \\
\vdots \\
\vdots \\
0 \\
z \\
Z \\
Z\end{array}$} & & & & & & & \\
\hline & & & & & & & \\
\hline & & & & & & & \\
\hline & & & & & & & \\
\hline & & & & & & & \\
\hline & & & & & & & \\
\hline & & & & & & & \\
\hline $\begin{array}{r}800 \\
700 \\
600 \\
500 \\
400 \\
300 \\
200 \\
100 \\
0\end{array}$ & 0 & 25 & 50 & 70 & 85 & 90 & 100 \\
\hline - P010 & 140 & 186 & 291 & 455 & 538 & 579 & 655 \\
\hline —P015 & 144 & 200 & 318 & 489 & 583 & 562 & 599 \\
\hline$=P 020$ & 187 & 306 & 385 & 487 & 558 & 557 & 596 \\
\hline - P030 & 51 & 159 & 346 & 432 & 549 & 541 & 604 \\
\hline -P040 & 64 & 158 & 338 & 441 & 550 & 569 & 575 \\
\hline P0100 & 234 & 218 & 340 & 412 & 499 & 537 & 553 \\
\hline Diesel & 119 & 199 & 367 & 569 & 642 & 701 & 703 \\
\hline
\end{tabular}

Fig.7. NOx Emissions vs. LOAD for All Palm Oil Blends and Diesel 


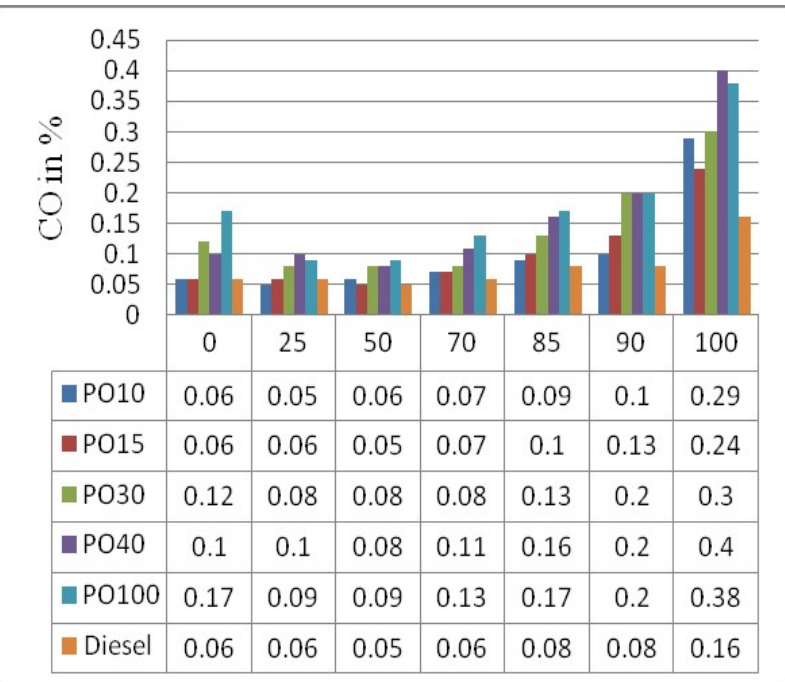

Fig.8. CO emissions vs. LOAD for All Blends of Palm Oil and Diesel

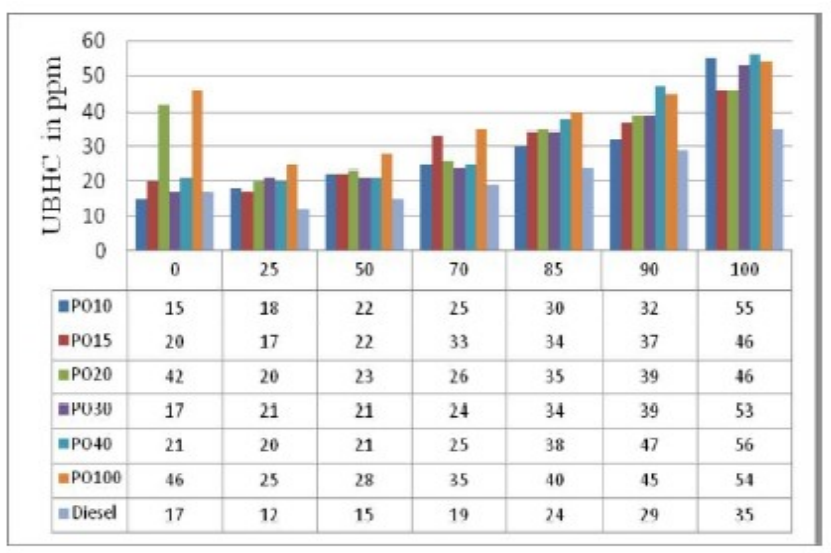

Fig.9.unburnt hydrocarbon emissions(ubhc) vs load for all palm oil blends and diesel

\section{Paper 10}

Review of this paper gives the experimental investigations on 4 stroke low heat rejection CI engine using alternative fuels.

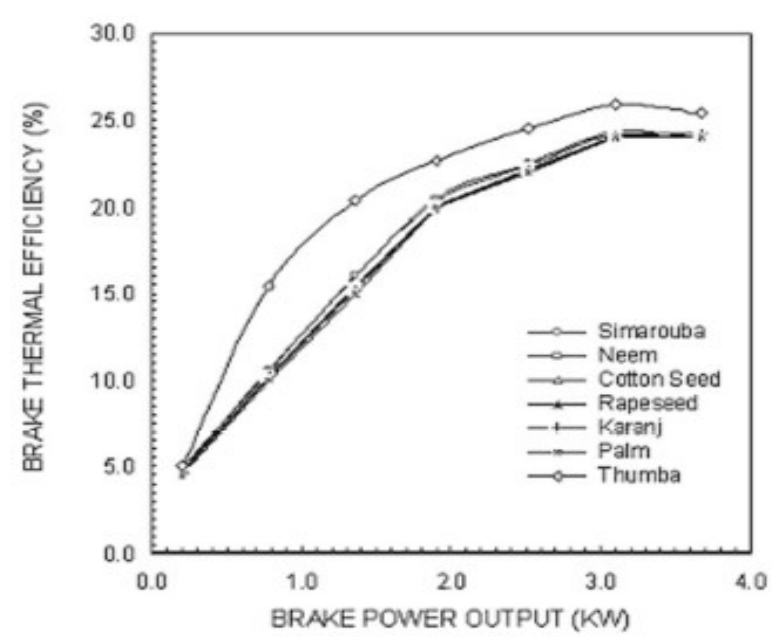

Fig.10.comparison of brakethermal number efficiency with power ouput for different vegetable oils in LHR engine.

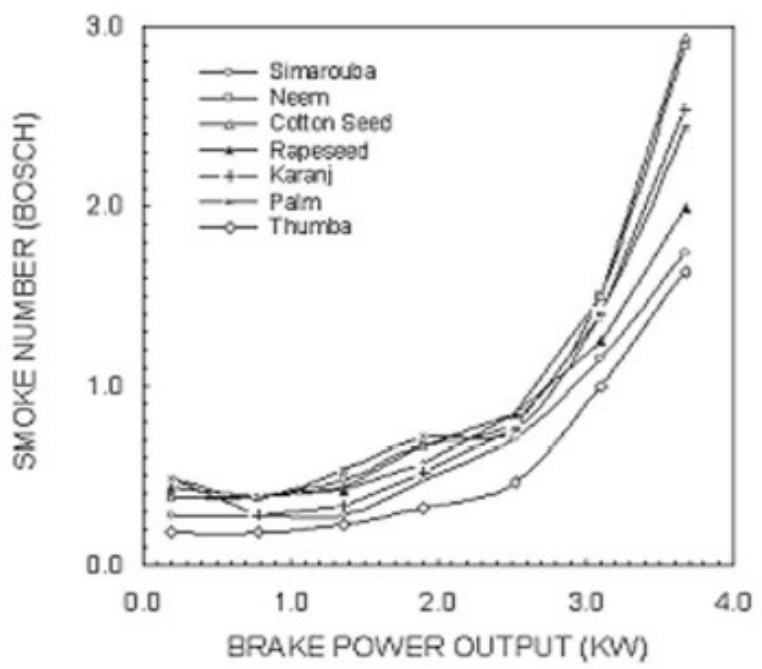

Fig.11.comparison smoke with power output with different vegetable oils in LHR engine.

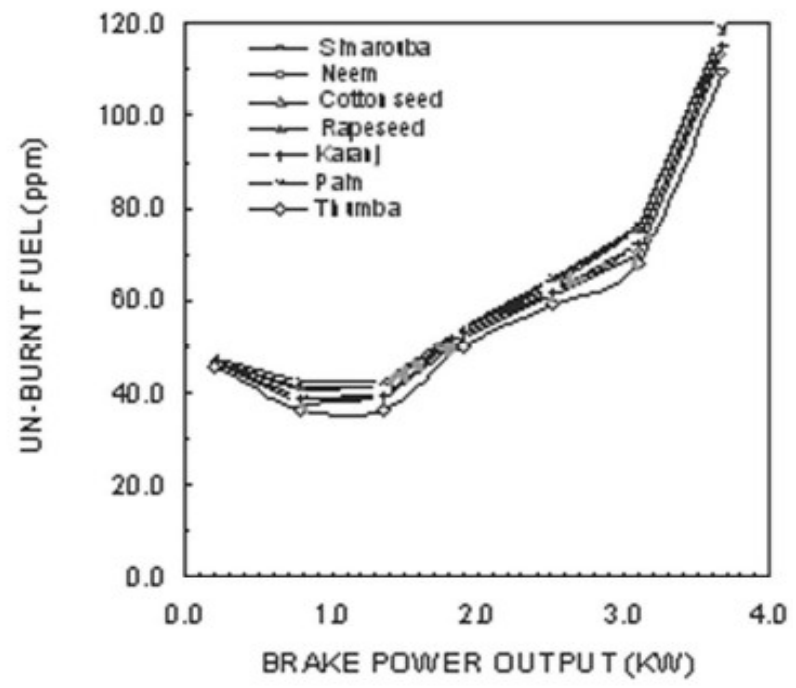

Fig.12.comparison of unburnt fuel emission with power output for different vegetable oils in LHR engine.

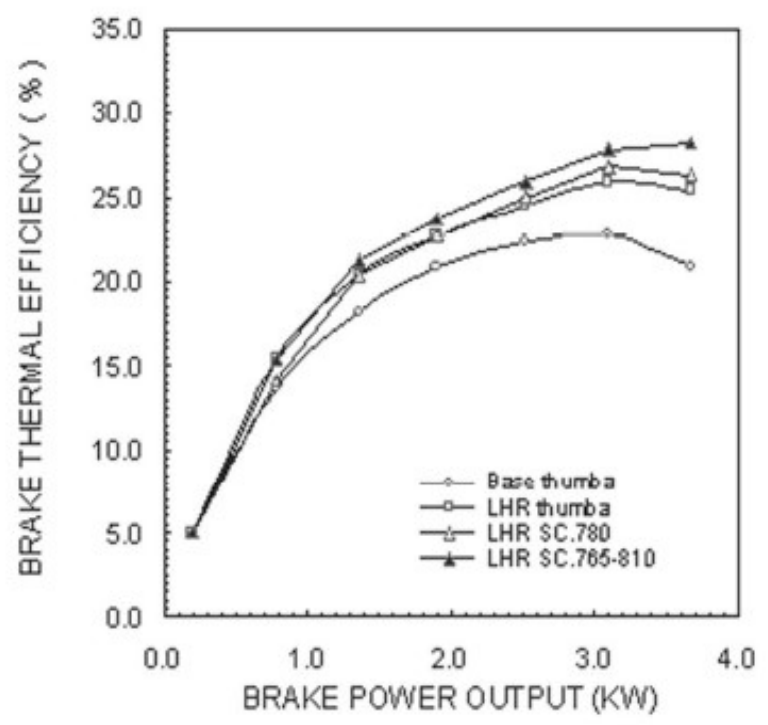

Fig.13.brake power output vs brake thermal efficiency with supercharging 


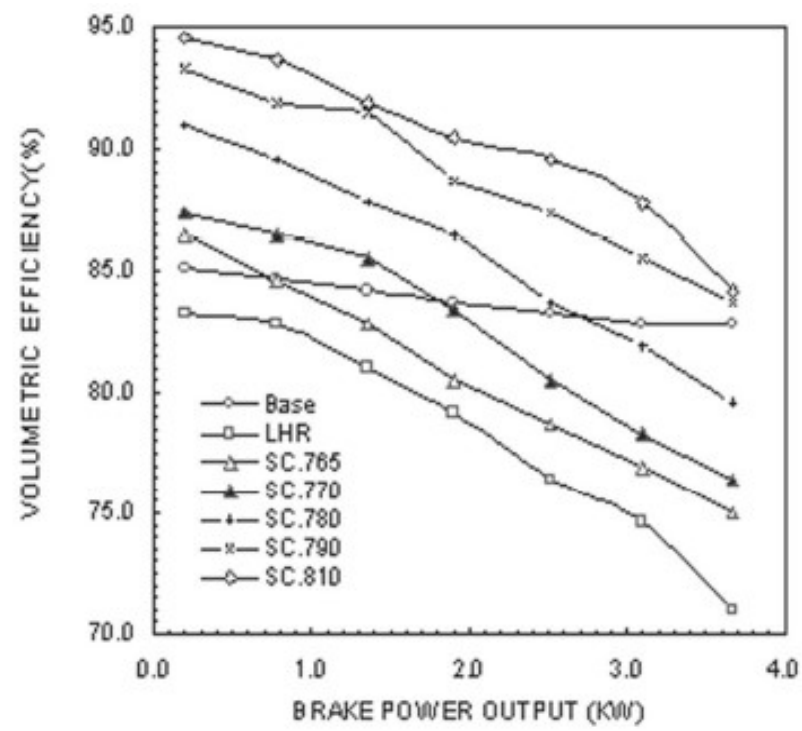

Fig.14.brakepower output vs volumetric efficiency with supercharging

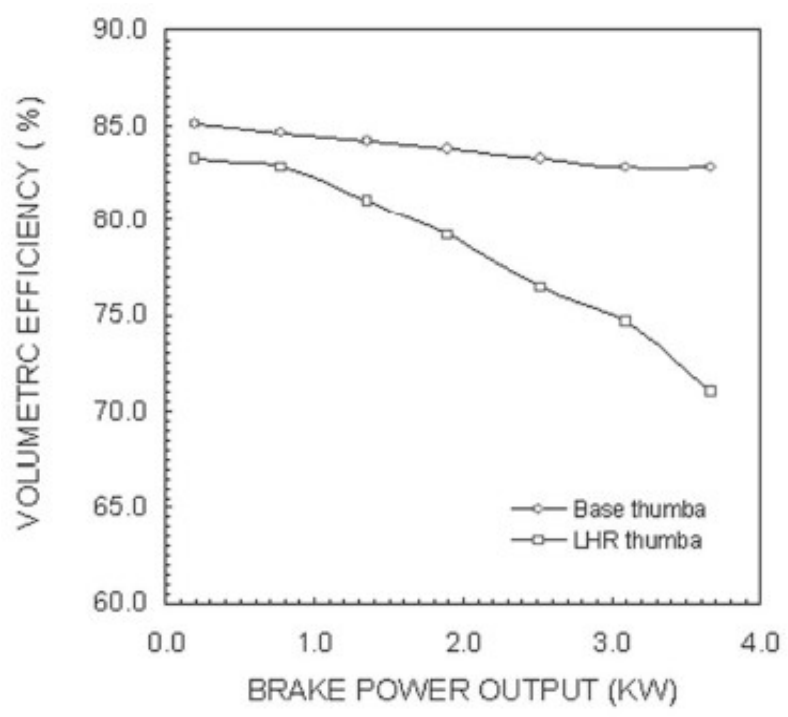

Fig.15.brake power output vs volumetric efficiency

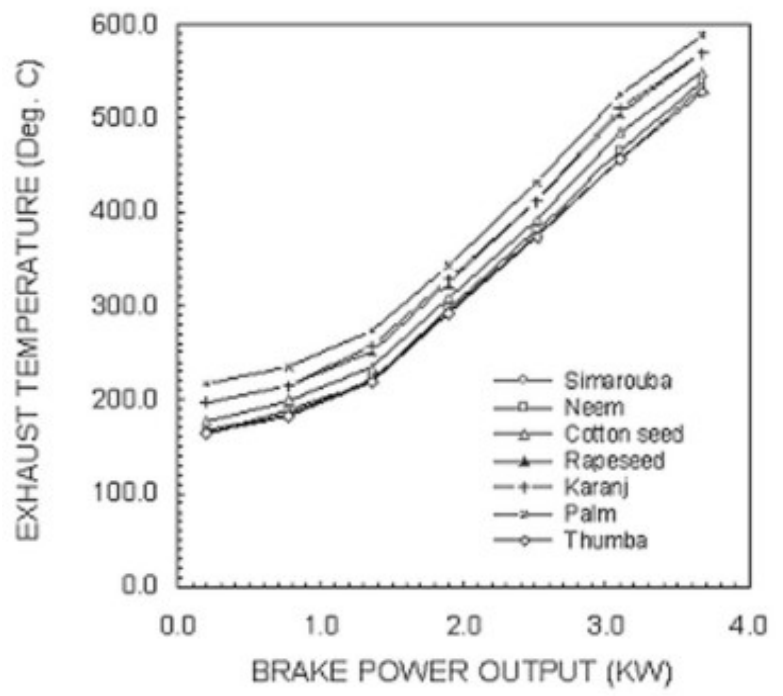

Fig.16.comparison of exhaust temperature with power output for different vegetable oils in LHR engine

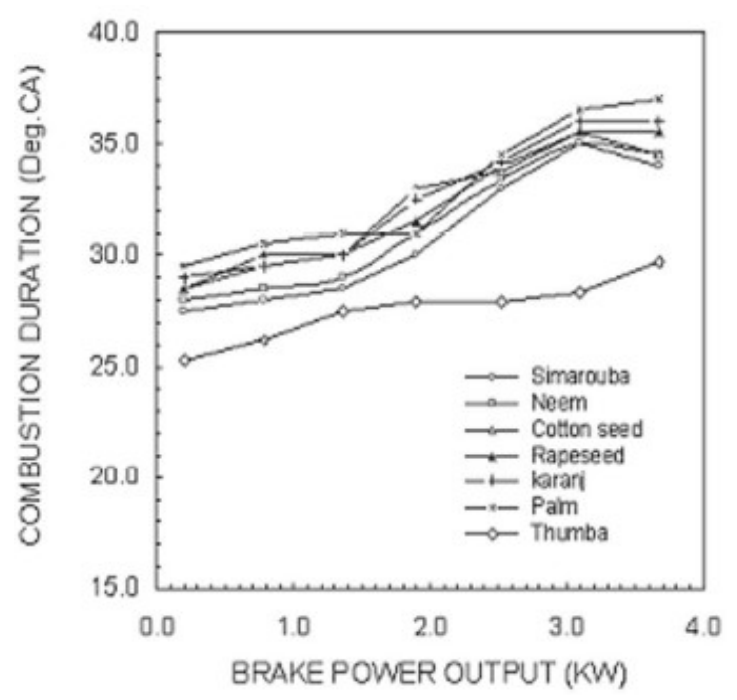

Fig.17.comparison of ignition delay with power output for different vegetable oils in LHR engine

\section{Paper 11}

This paper gives the knowledge on turbocharging of diesel engine for improving performance and exhaust emissions.

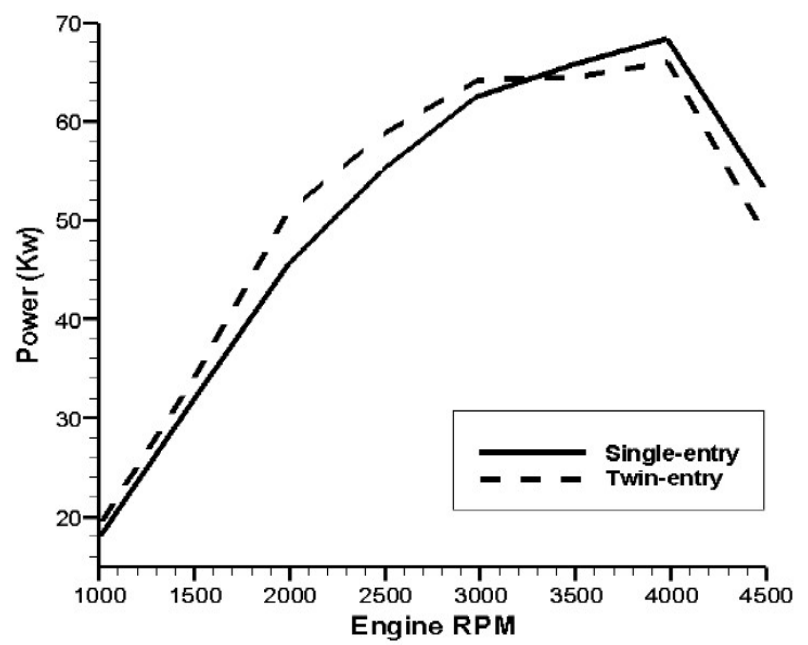

Fig.18. Increased engine power output of a 2.0L CI engine using a twin-entry Turbocharger

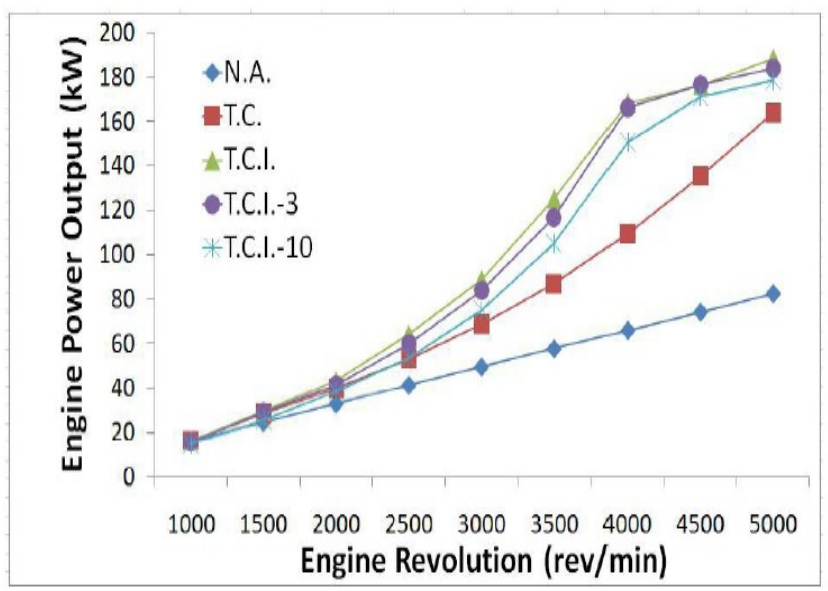

Fig.19. Engine power output vs. engine revolution. 


\section{CONCLUSION}

The review study presented in this paper provides the basic knowledge on useful alternative fuels for IC engines. This study gives the technologies namely thermal barrier coating and turbocharging to improve efficiency of IC engine and also to reduce the exhaust gas emissions such $\mathrm{HC}, \mathrm{CO}, \mathrm{CO}_{2}$ and PM emissions by using biodiesel blends. From the peer reviewed results it is found that the review study has the future scope in using nonedible oil as a biodiesel if the piston is coated with thermal barrier material and a turbocharger is fixed to the engine properly to use exhaust gas energy. Thus decreasing exhaust gas emissions, increasing efficiency of engine and reducing cost of fuel.

\section{REFERENCES}

[1] JOURNAL OF FOREST PRODUCTS \& INDUSTRIES, 2015, 4(2), 80-85 ISSN: 23254513(PRINT) ISSN 2325 - 453X (ONLINE)

[2] International Journal of Science, Environment ISSN 2278-3687 (O) and Technology, Vol. 3, No 4, 2014, $1544-1562$

[3] Renewable and Sustainable Energy Reviews 31 (2014) 650-656

[4] INTERNATIONAL JOURNAL OF ENERGY RESEARCH Int. J. Energy Res. 2015; 39:1295-1310 Published online 31 March 2015 in Wiley Online Library (wileyonlinelibrary.com). DOI: 10.1002/er.3334

[5] Jagadish, D., et al.: The Effect of Supercharging on Performance and Emission... THERMAL SCIENCE, Year 2011, Vol. 15, No. 4, pp. 1165-1174 1165

[6] National Conference on Recent Trends and Developments in Sustainable Green Technologies Journal of Chemical and Pharmaceutical Sciences www.jchps.com ISSN: 0974-2115

[7] ISSN: 2277-3754 ISO 9001:2008 Certified International Journal of Engineering and Innovative Technology (IJEIT) Volume 3, Issue 1, July 2013

[8] INTERNATIONAL JOURNAL OF MECHANICAL ENGINEERING AND TECHNOLOGY (IJMET) ISSN 0976 - 6340 (Print) ISSN 0976 - 6359 (Online) Volume 4, Issue 1, January- February (2013), pp. 142149 (C) IAEME: www.iaeme.com/ijmet.asp Journal Impact Factor (2012): 3.8071 (Calculated by GISI)

[9] International Journal of Science, Engineering and Technology Research (IJSETR), Volume 5, Issue 1, January 2016119

[10] INTERNATIONAL JOURNAL OF RESEARCH IN AERONAUTICAL AND MECHANICAL ENGINEERING

[11] IOSR Journal of Mechanical and Civil Engineering (IOSR-JMCE) e-ISSN: 2278-1684,p-ISSN: 2320334X, Volume 12, Issue 4 Ver. III (Jul. - Aug. 2015), PP 22-29 www.iosrjournals.org 